\title{
Eksistensi Serikat Pekerja/Serikat Buruh dalam Upaya Mensejahterakan Pekerja
}

\author{
Zulkarnain Ibrahim
}

DATA NASKAH

Masuk: 30 Juli 2015

Diterima: 20 Juni 2016

Terbit: 8 Desember 2016

KORESPONDEN PENULIS:

Fakultas Hukum Universitas Sriwijaya Jalan Srijaya Negara, Bukit Besar, llir Barat I, Palembang, Sumatera Selatan Email:zulibrahim007@gmail.com

\section{ABSTRACT}

The exsistence of Labour Union do not implement the mandate of Laws. No. 21 year 2000 about Labour Union, also in covering, defensing the right/obligation of workers, and welfare of workers and their family. Informal workers not yet and should become the member of Labour Union, because they become the Indonesia's economic strength/endurance. So that Labour Union convince goverment to help with technical guidance, management, and banking with low interest. General obstacle of Labour Union, weak in leadership's quality and bargaining with businessmen. The personal/group needs, become the reason of fragmentation from time to time, and the vision/mission has not yet maximally executed to facing the future. The Labour Union should execute right/obligation from laws, making the members become professional in their fields, and harmonic with members and also bussinesmen.

Key words: Labour union, prosper, workers

\section{ABSTRAK}

Eksistensi Serikat Pekerja/Serikat Buruhbelum melaksanakan amanat Undang-Undang Nomor: 21 Tahun 2000 TentangSerikat Pekerja/Serikat Buruh, baik perlindungan, pembelaan hak/kepentingan pekerja, dan peningkatan kesejahteraan pekerja dan keluarganya. Pekerja informal belum dan harus jadi anggotaSerikat Pekerja/Serikat Buruh, sebab mereka menjadi kekuatan/ketahanan ekonomi Indonesia, maka Serikat Pekerja/ Serikat Buruh meyakinkan pemerintah untuk membantu dengan bimbingan teknis, manjemen, dan perbankan dengan bunga yang ringan. Kendala umumSerikat Pekerja/Serikat Buruh, lemah dalam kualitas kepemimpinan dan tawar-menawar dengan pengusaha. Kepentingan pribadi/golongan, menjadi alasan perpecahan dari waktu ke waktu, dan visi/misi tidak belum dilaksanakan secara maksimal untuk menyongsong masa depan. Serikat Pekerja/Serikat Buruhharus melaksanakan hak/ kewajiban dari undang-undang, menjadikan anggotanya profesional di 
bidangnya, dan harmonis dengan anggota serta pengusaha.

Kata Kunci: Serikat pekerja, mensejahterakan, pekerja.

\section{PENDAHULUAN}

Salah satu unsur dalam hubungan industrial atau kegiatan perusahaan adalah pekerja. Motivasi pekerja sekarang di samping pengabdian kepada bangsa dan negara, juga merupakan upaya untuk memenuhi berbagai macam kebutuhan.Namun kenyataannya pada akhir-akhir ini, masyarakat pekerja sering tidak tahu makna bekerja, karena penghasilan yang didapat tidak dapat mensejahterakan diri dan keluarganya.

Lemahnya tingkat kesejahteraan di negara-negara berkembang, karena trend globalisasi. globalisasi menyebabkan kesejahteraan sekarang susah didapat oleh rakyat, antara lain karena: 1) globalisasi menempatkan persaingan langsung antara orang-orang yang tidak pernah akan bertemu; 2) persaingan cara ini akan menciptakan "perlombaan menuju kehancuran" (race to the bottom) yang menyangkut standar buruh dan lingkungan; 3) perlindungan sosial sulit untuk dibiayai, bila pemilik modal tidak dikenakan pajak. Sedangkan pemerintah memotong pajak dari gaji, upah dan biaya konsumsi;4) secara sistimatik meniadakan biaya untuk urusan lingkungan dan sosial (Susan George, 2008: 177).

Karena itu, George tiba pada analisis, bahwa apa yang dinamakan globalisasi sesungguhnya telah menghianati prinsip-prinsip welfare state, karena apa yang sebelumnya sesuai dengan prinsip welfare state merupakan monopoli alamiah negara, yaitu sektor-sektor yang termasuk bidang pelayanan publik dan kesejahteraan sosial diserahkan kepada swasta dengan alasan tidak efisien (Susan George, 2008: 178).

Sebenarnya para Pendiri Republik Indonesia telah mencanangkan welfare state dalam Pembukaan UndangUndang Dasar Negara Republik Indonesia Tahun 1945, yang selanjutnya disebut UUD NRI Tahun 1945 dengan diikuti Batang Tubuh pada Pasal 33 dan 34. Mengapa kita sangat berkepentingan dengan perubahan UUD NRI Tahun 1945, khususnya Pasal 33 dan 34 ? Banyak jawaban dapat diberikan, antara lain: 1) keinginan kita untuk mejadi negara yang sejahtera, karena sebagian besar rakyat belum menikmatinya;
2) keadilan dibidang ekonomi masih berpihak kepada golongan menengah dan atas; 3) arah kebijakan pemerintah di bidang ekonomi untuk mengentaskan kemiskinan berjalan di tempat.

Sebagian dari rakyat yang belum menikmati kesejahteraan, adalah pekerja atau buruh. Sedangkan perlindungan terhadap pekerja secara normatif telah dijamin dalam Perundang-undangan Ketenagakerjaan. Undang-Undang Nomor: 21 Tahun 2000,tentang Serikat Pekerja/Serikat Buruh (selanjutnya, UU No. 21 Tahun 2000), telah menentukan perpanjangan tangan negara untuk membela hak-hak dan kepentingan pekerja. Negara menjamin hak hak dasar pekerja dan menjamin kesamaan kesempatan serta perlakuan tanpa diskriminasi atas dasar apapun untuk mewujudkan kesejahteraan pekerja dan keluarganya dengan tetap memperhatikan perkembangan kemajuan dunia usaha.

Berdasarkan uraian di atas, maka permasalahan penelitian hukum ini adalah:Bagaimanaeksistensi Serikat Pekerja/Serikat Buruh dalam upaya mensejahterakan Pekerja?

\section{PEMBAHASAN}

\section{A. Eksistensi Serikat Pekerja/Serikat Buruh}

John Locke dengan menggunakan konstruksi hukum, mengupas tentang perjanjian kemasyarakatan yang bertujuan untuk menjamin hidup, kebebasan, dan hak milik rakyat dan bahwa pemerintah harus menghormati Hak Asasi Manusia, selanjutnya disebut HAM. Makna perjanjian tersebut terletak pada adanya jaminan atas hak-hak tersebut. HAM menurut cara pikir ini mempunyai sifat pra-konstitusional. HAM merupakan hak yang diterima terlepas dari ikatan kenegaraan (statsverband). Suatu ikatan kenegaraan yang tidak menjamin HAM sebenarnya telah hilang dasar keberadaannya (Harifin A. Tumpa, 2010: 54).

International Commission of Jurists yang merupakan suatu organisasi ahli hukum internasional dalam konferensinya di Bangkok tahun 1965 memperluas konsep rule of law in the modern age, mengemukakan bahwa syarat-syarat dasar untuk terselenggaranya pemerintah yang demokratis di bawah rule of law ialah: 1) perlindungan konstitusionil, 2) badan kehakiman yang bebas dan tidak memihak (independent and impartial tribuna/s), 3) pemilihan umum yang bebas, 4) kebebasan untuk menyatakan pendapat, 5) 


\section{MEDIA
HUKUM}

kebebasan untuk berserikat atau berorganisasi dan beroposisi, 6) pendidikan kewarganegaran (Edie Toet Hendratno, 2009: 76).

Kebebasan berserikat, termasuk bagian dari HAM. Perlindungan terhadap pekerja termasuk jaminan hak berserikat, telah lama diperjuangkan oleh ILO. Brian Burkett menyatakan bahwa:pertama,jumlah negara anggota ILO telah berkembang dari 42 yang asli pada tahun 1919, menjadi 177 pada tahun 2004. Antara 1919 dan 2003, ILO mengadakan 185 konvensi dan 194 rekomendasi. Konvensi dan rekomendasi ini berkaitan erat dengan masalah yang luas mengenai hukum buruh dan kebijakan sosial: hak-hak dasar (kebebasan berserikat, perundingan kolektif, kesetaraan dalam pekerjaan), kondisi kerja, pekerja anak, perlindungan pekerja perempuan, jam kerja, inspeksi buruh, bimbingan dan pelatihan kejuruan, masalah keamanan sosial, dan kesehatan dan keselamatan; Kedua, Deklarasi ILO tentang Prinsip dan Hak Dasar di Tempat Kerja ("Deklarasi Fundamental"). Dokumen ini memberikan definisi konsensus dari empat standar pokok perburuhan yang telah menjadi pusat dari standar kerja global. Deklarasi Fundamental berpendapat bahwa empat standar pokok adalah: (a) kebebasan berserikat dan pengakuan efektivitas terhadap hak untuk berunding bersama, (b) penghapusan segala bentuk kerja paksa atau kerja wajib; (c) penghapusan efektif pekerja anak, dan (d) penghapusan diskriminasi dalam hal pekerjaan dan jabatan; dan Ketiga, posisi ILO sebagai badan penetapan standar unggul internasional tentang isu-isu perburuhan telah memungkinkan untuk menegaskan dampak yang berarti terhadap pengembangan sistem regional. Seperti yang akan dibahas di bawah, melindungi prinsip-prinsip kerja fundamental telah menjadi fokus diskusi dalam Uni Eropa, NAFTA, Mercosur, dan KTT Proses Amerika. Selain itu, perdebatan sekitar "Klausul Sosial" dalam Organisasi Perdagangan Dunia sebagian besar berpusat pada proposal untuk menghubungkan liberalisasi perdagangan agar menghormati standar yang ditetapkan dalam Deklarasi Fundamental. ILO demikian tetap "depan dan pusat" di semua diskusi tentang dimensi buruh internasional (Brian Burkett, 2006: 19-20).

Indonesia sebagai salah satu anggota ILO, telah menserasikan asas-asas kebebasan berserikat dalam UU NO. 21 Tahun 2000, dengan dimungkinkan dibentuk Serikat
Pekerja/Serikat Buruhlebih dari satu. Hal ini menyebabkan keberadaan Serikat Pekerja/Serikat Buruhbanyak didirikan di satu perusahaan. Sayangnya karena ketidak-siapan buruh melaksanakan hak berserikat dimanfaatkan oleh oknum tertentu untuk mengeruk keuntungan bagi kepentingannya sendiri dengan menjual bangsa. Dikatakan demikian karena berdasarkan UU No. 21 Tahun 2000 diperbolehkan Serikat Pekerja/ Serikat Buruh itu menerima sumbangan dana dari negara lain. Sering pula keberadaan yang lebih dari satu jumlahnya di satu perusahaan justru memicu terjadinya perselisihan perburuhan yang dapat berakibat mogok kerja yang seharusnya justru bertentangan dengan tujuan disahkannya UU No. 21 tahun 2000 tersebut(Asri Wijayanti, 2009: 78)

Meskipun kebebasan serikat buruh telah dijamin oleh Konvensi PBB / ILO, UUD NRI Tahun 1945 dan UU. No. 21 tahun 2000, namun kekebasan berserikat tersebut masih harus diperjuangkan. Sebab yang nampak hanya kebebasan secara formal, nampak yang dilihat dari luar perusahaan. Sedangkan kebebasan sesungguhnya untuk menuntut hakhak normatif di lingkungan perusahaan, sangat sulit untuk didapatkan.Serikat Pekerja/Serikat Buruhpada suatu perusahaan baru dapat terbentuk, apabila mempunyai anggota paling sedikit 10 orang anggota. Sedangkan di bidang kerja informal, pada umumnya pekerjanya kurang dari 10 orang, tidak wajib mendirikan Serikat Pekerja/Serikat Buruhdan hampir-hampir tidak terdatakan.

Malahan menurut Arturo Bronstein, beberapa data otomatis, mengkatagorikan semua pekerja di perusahaanperusahaan mikro yang mempekerjakan kurang dari 5 orang, sebagai pekerja informal. Pekerja rumah tangga termasuk dalam defenisi ekonomi informal yang terdapat di banyak negara, tetapi tidak dapat disamakan. Keadaan ekonomi informal,memiliki kreteria sebagai berikut: 1) sebagian besar pekerja informal tidak tercatat dan terdaftar dalam statistik resmi. Namun, mereka kadang-kadang dicatat pada rumah tangga dan tenaga kerja dengan kekuatan survey yang akurat; 2) pekerja informal memilki sebagian akses ke sisi kridit, integrasi pasar dalam ekonomi formal, pendidikan formal atau lembaga pelatihan. Sehingga mereka juga sering dikucilkan dari layanan publik dan fasilitasnya; 3) pekerja informal tidak diakui, didukung atau diatur. Inilah 


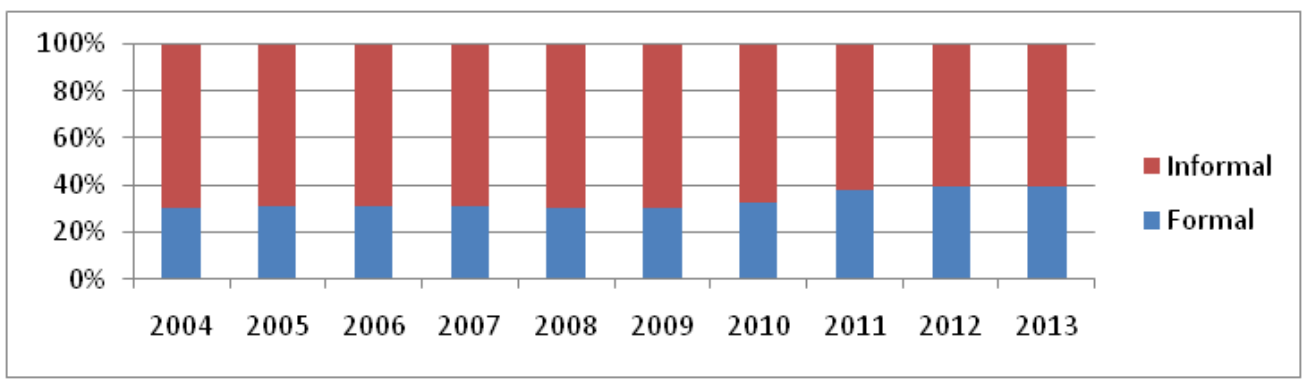

Sumber: Aviliani, Biaya Tenaga Kerja di Indonesia, disampaikan pada Forum Konsolidasi Dewan Pengupahan se Indonesia, Jakarta, tanggal 3-5 September 2013 (Sumber ini diolah dari BPS 2013).

fitur dasar yang membedakan sektor informal dari usaha kecil yang bekerja dalam batas-batas hukum tertentu; dan 4) dalam kebanyakan kasus pekerja yang berada di luar lingkup tindakan serikat pekerja dan organisasi pengusaha, mereka sering dapat mengatur fakta yang terdapat di sejumlah negara serta mereka telah membentuk asosiasi, termasuk serikat pekerja (Arturo Bronstein, 19: 34-35).

Pekerja sektor informal ini, tidak diakui atau ditekan. Selain itu, ada perbedaan derajat dengan sektor formal. Sedangkan beberapa kegiatan informal jelas sesuai dengan kreteria di atas, dan mungkin yang lainnya mematuhi beberapa peraturan, sehingga mereka menjadi formal dalam arti tertentu dan informal dalam satu sama lainnya. Untuk pekerja formal saja di Indonesia, belum semua menjadi anggota Serikat Pekerja/Serikat Buruh, pekerja informal semuanya belum menjadi anggotaSerikat Pekerja/Serikat Buruh. Sedangkan jumlah pekerja formal lebih besar dari pekerja formal, dapat dilihat pada tabel berikut ini. Aviliani menjelaskan bahwa sektor informal menyerap hingga 60,02 persen tenaga kerja nasional sisanya 39, 98 persen tenaga kerja formal (Aviliani, 2013: 5)

Besarnya tenaga kerja sektor informal, telah membuktikan ketahanan ekonomi Indonesia ketika terjadi krisi moneter di tahun 1998-an. Sedangkan sektor formal tidak dapat bertahan di dalam bisnisnya, karena dipengaruhi oleh fluktuasi nilai dollar dan ekonomi negara lain. Karena banyak perusahaan yang pailit (seperti di sektor perbankan), berdampak PHK terhadap pekerja. Maka pemerintah, hendaknya memperhatikan juga kesejahteraan pekerja sektor informal yang jumlahnya di atas 60 persen dibandingkan pekerja sektor formal. Bantuan pemerintah di bidang perbankan dengan dana dan bunga yang ringan serta bimbingan teknis terhadap usaha-usaha sektor informal, sangat membantu kualitas kesejahteraan mereka. Di samping itu Program Jamsostek, Jaminan Kesehatan, dan Beasiswa; dapat ditingkatkan jumlah kepesertaannya dan kualitasnya. Sedangkan untuk pekerja informal per-daerah, menunjukkan bahwa antara tahun 2001 dengan tahun 2010 tidak menunjukkan perbedaan yang signifikan seperti dilihat pada tabel berikut ini (Peter van Rooij, 2011: 6).

Di Swedia sebagai pembanding, semua pekerja formal dan informal menjadi anggota Serikat Pekerja. Di Swedia melalui serikat, dan tidak ada saluran independen bagi pribadi-pribadi pekerja, tetapi ada pengecualian dalam hukum bagi pekerja pribadi secara independen di dewan karya Eropah. Sementara dewan kerja mewakili semua pekerja, toko-toko lokal Swedia (fackklubbar) juga anggota serikat pekerja. Tingkat pusat tidak diragukan lagi kuat, tapi begitu pula lokal.Toko-toko lokal merupakan bagian penting dari struktur serikat pekerja karena mereka adalah wajah dari serikat buruh terhadap anggota individu.Menggunakan data dari 15 negara Eropa, Visser juga menyimpulkan bahwa representasi tempat kerja memiliki efek positif pada unionisation. Namun, banyak perusahaan kecil tidak memiliki toko-toko lokal. Sebagian besar hubungan pengusaha-pekerja telah dilakukan melalui negosiasi, tidak hanya untuk upah tetapi juga menyangkut hal lainnya di Swedia (Sofia Murhem, 2006: 10-11). 
Tabel 2

Pekerja Informal Per-Daerah

\section{Pekerja Informal Per-Daerah}

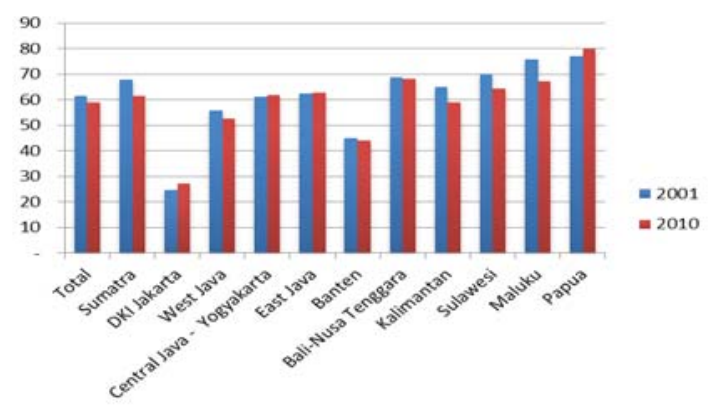

Sumber: Peter van Rooij, Direktur ILO Indonesia dan Timor Leste

Swedia memiliki serikat buruh dengan persentase tertinggi di Eropa Barat. Tradisi korporatis mungkin telah berkontribusi untuk ini, serta membuat serikat buruh berpengaruh. Juga fakta bahwa menurut hukum perburuhan, serikat pekerja adalah badan hukum. Karena serikat buruh kuat dan harmonis dengan anggota, maka pada tingkat pusat, mereka berpengaruh secara politis dan kuat bernegosiasi dengan pengusaha.

\section{B. Kewajiban Serikat Pekerja/Serikat Buruh}

\section{dalam Upaya Pensejahteraan Pekerja}

Serikat pekerja di berbagai negara, paling sedikit mempunyai tiga fungsi, yaitu:1) serikat pekerja adalah lembaga yang melakukan perundingan dengan pengusaha tentang upah dan kondisi kerja; 2) serikat pekerja adalah bagian dari gerakan sosial yang bertujuan untuk memperbaiki kondisi kehidupan para pekerja; dan 3) serikat pekerja adalah kelompok penekan yang mempengaruhi parlemen, pemerintah dan administrasi publik. Sepanjang abad ke-20, posisi Serikat pekerja telah diterima secara umum, telah menjadi bagian yang kuat dan lebih terintegrasi kerangka kelembagaannya untuk negosiasi dari: upah, jam kerja, dan konsisi kerja (Thomas P. Boje dan Bengt Furaker, 2003: 12).

UU. No. 21 Tahun 2000, menjelaskan bahwa Serikat Pekerja/Serikat Buruhadalah organisasi yang dibentuk dari, oleh, dan untuk pekerja/buruh baik di perusahaan maupun di luar perusahaan, yang bersifat bebas, terbuka, mandiri, demokratis, dan bertanggung jawab guna memperjuangkan, membela serta melindungi hak dan kepentingan pekerja/ buruh serta meningkatkan kesejahteraan pekerja/buruh dan keluarganya.

Sedangkan asas, sifat dan tujuan Serikat Pekerja/Serikat Buruh, diatur dalam Pasal-pasal berikut: 1) menerima Pancasila sebagai dasar negara dan UUD NRI Tahun 1945 sebagai konstitusi Negara Kesatuan Republik Indonesia; 2) mempunyai asas yang tidak bertentangan dengan Pancasila dan UUD NRI Tahun 1945; 3) mempunyai sifat bebas, terbuka, mandiri, demokratis, dan bertanggung jawab; 4) bertujuan memberikan perlindungan, pembelaan hak dan kepentingan, serta meningkatkan kesejahteraan yang layak bagi pekerja / buruh dan keluarganya.

Kemudian hak Serikat Pekerja/Serikat Buruh, sebagai berikut: pertama, a) membuat perjanjian kerja bersama dengan pengusaha; b) mewakili pekerjaan/ buruh dalam menyelesaikan perselisihan industrial; c) mewakili pekerja/ buruh dalam lembaga ketenagakerjaan; d) membentuk lembaga atau melakukan kegiatan yang berkaitan dengan usaha peningkatan kesejahteraan pekerja/buruh; e) melakukan kegiatan lainnya dibidang ketenagakerjaan yang tidak bertentangan dengan peraturan perundang-undangan yang berlaku.

Kedua, berkewajiban Serikat Pekerja/Serikat Buruh: a) melindungi dan membela anggota dari pelanggaran hakhak dan memperjuangkan kepentingannya; b) memperjuangkan peningkatan kesejahteraan anggota dan keluarganya; c) mempertanggungjawabkan kegiatan organisasi kepada anggotanya sesuai dengan anggaran dasar dan anggaran rumah tangga.

Pelaksanaan aktivitas Serikat Pekerja/Serikat Buruh dalam mengelola organisasinya, harus menerapkan standar demokrasi yang tumbuh dari bawah atau anggotanya. Sikap demokrasi Serikat Pekerja/Serikat Buruhberguna memperjuangkan, membela serta melindungi hak dan kepentingan pekerja/buruh serta meningkatkan kesejahteraan pekerja/buruh dan keluarganya.

Tujuannya memberikan perlindungan, pembelaan hak dan kepentingan serta meningkatkan kesejahteraan yang layak bagi pekerja/buruh dan keluarganya. Dapat kita lihat antara lain dari dua sudut pandang, sebagai berikut: pertama, sudut 
pandang pekerja/buruh dalam hal eksploitasi dan diskriminasi; Jika diamati dari fakta upah yang dibayarkan kepada pekerja, pada umumnya pemerasan bukan sekedar pelanggaran sosial lagi. Menurut M. Yahya Harahap tindakan pengusaha telah menindas dan memeras pekerja untuk menumpuk kekayaan yang melimpah bagi pihak pengusaha. Upah yang diterima, tidak sesuai dengan struktur upah yang realistis dan aktual, yang mereka terima jauh dari pemenuhan standar kebutuhan pokok (primary need). Hal ini sama sekali tidak mungkin memenuhi jaminan kehidupan (M. Yahya Harahap, 1995: 145; Zulkarnain Ibrahim, 2011: 4)

Masalah pengupahan dan pelanggaran UMR, secara hukum yang bertindak sebagai class action tentunya Federasi Serikat Pekerja Seluruh Indonesia. FSPSI dapat tampil sebagai class action menuntut ganti rugi terhadap perusahaan atas nama pekerja, apabila suatu perusahaan dijatuhi pidana atas pelanggaran Upah Minimal Regional. Atau badan Lembaga Swadaya Masyarakat, dapat tampil ke depan sebagai class action mewakili kepentingan pekerja. Asosiasi atau kantor advokat pun dapat tampil sebagi class action. Namun, sampai sekarang begitu besar nama SPSI dan begitu banyak Lembaga Swadaya Masyarakat dan berserakan kantor pengacara, belum ada yang mau tampil sebagi class action. Padahal disinilah fungsi-fungsi lembaga dimaksud, bersedia menjadi "class representative" menuntut pemenuhan kepentingan kelompok "the powerless (tak berdaya-para pekerja) berhadapan dengan pihak "the powerfull(yang kuat-para pengusaha). Cara-cara penegakan hukum dalam bentuk class action baik di bidang ketenagakerjaan dan lingkungan hidup sudah waktunya dikembangkan di Indonesia, sebagaimana yang sudah berkembang di Ameriak Serikat atau negara lain.

Kedua, Sudut pandang pengusaha, dalam hal saksi pidana kejahatan. dalam Undang-undang Serikat Pekerja/ Serikat Buruh paling singkat 1 tahun dan paling lama 5 tahun dan/atau denda paling sedikit Rp. 100.000.000,- dan paling banyak Rp. 500.000.000,-. Seandainya sanksi pidana ini dilaksanakan nantinya secara berlebihan, bukan mustahil akan menjadi bumerang bagi pekerja. Jika ditinjau dari pembentukan Hukum Nasional, patut diperhatikan pendapat Hernando De Soto dalam bukunya: "The Other Path" bahwa rancangan undang-undang akan disertai analisis biaya- manfaat atau "cost-benefit analysis" dari kemungkinan pengaruhnya dibidang sosial ekonomi. Alasannya: pertama, cara ini akan mengidentitas dan hampir secara otomatis menyingkirkan undang-undang yang menciptakan hambatan yang tidak perlu. Kedua, karena banyaknya peraturan merkantilis (dibidang perdagangan) yang tidak mempunyai dasar yang jitu, suatu rancangan yang kurang baik akan ditolak pada masyarakat yang sudah krisis. Ketiga, kalau memang ada rancangan yang baik, tetapi ongkosnya melebihi keuntungan atau kegunaannya, cukup alasan untuk menolaknya(M. Yahya Harahap, 1995: 147; Zulkarnain Ibrahim, 2011: 5)

Fungsi Serikat Pekerja/Serikat Buruh, pertama, sebagai pihak dalam pembuatan perjanjian kerja bersama atau PKB. Dasar PKB adalah: 1) hubungan industrial Pancasila berpandangan bahwa antara pekerja dan pengusaha terdapat hubungan yang bersifat kekeluargaan dan gotong-royong, 2) mereka bebas melakukan perundingan dan memuat perjanjian asal saja, tetapi memperhatikan kepentingan yang lebih luas, yaitu masyarakat, bangsa, dan negara; 3) dibuat melalui musyawarah untuk mufakat, tidak melalui kekuatan tawar-menawar, tetapi yang diperlukan sifat yang keterbukaan, kejujuran, dan pemahaman terhadap kepentingan semua pihak. Kehadiran Serikat Pekerja/Serikat Buruhdalam rangka meningkatkan kerja sama dan tanggung jawab bersama, dan 4) hasilnya adalah suatu kesepakatan yang merupakan titik optimal yang bisa dicapai menurut kondisi yang ada, dengan memperhatikan kepentingan semua pihak (Asri Wijayanti, 2009: 92-93).

Oleh karena itu, menyangkal kebebasan berserikat sebagai hak politik rakyat (SP/SB pen.), dalam sistem demokrasi " hak-hak untuk berserikat dan berkumpul secara khusus dijamin oleh banyak konstitusi dan oleh Universal Declaration of Human Rights". Dengan jaminan-jaminan yang diberikan oleh konstitusi maupun oleh Universal Declaration of Human Rights, (Pradjoto, 1983: 13).

Meskipun pekerja sudah terampil dalam melaksanakan pekerjaan, namun menurut Ketua KSBSI hambatan internal SB sulit untuk diatasi, yaitu: 1) penyesuaian struktur SB yang lamban (birokratis); 2) pasar kerja berubah tapi model pengorganisasian belum berubah (lokasi kantor, rumah, jam kerja, sifat organiser, kapasitas pengurus lamban 


\section{MEDIA
HUKUM}

berkembang); 3) pendapatan SB dari iuran anggota semakin menipis; 4) terlalu mengandalkan penyelesaian konflik industrial melalui sistem hukum yang tersedia; 5) kemampuan lobby dan menggalang opini belum optimal; dan 6) aktivis kurang menguasai peta industri dan logika modal (PMA, relokasi, kultur pemodal).

Sebenarnya kelemahan umum dari SP/SB, disebabkan organisasi ini tidak kompak atau bersatunya anggota dikarenakan tidak patuh pada ADR/ART organisasi tersebut. Lemahnya keterampilan pekerja atau tidak ahli di bidangnya, maka posisi tawar pekerja dalam memperjuangkan upah yang layak menjadi lemah. Secara organisasi lemahnya fungsi Serikat Pekerja/Serikat Buruh itu sendiri menurut M. S. Hidayat disebut: tantangan abadi gerakan buruh Indonesia, sebagai berikut: 1) SB sebagai alat politik, 2) perpecahan yang tidak kunjung henti; 3) kekurangan kualitas dan kuantitas kepemimpinan; 4) kurangnya kesadaran menjadi anggota Serikat Pekerja/Serikat Buruh; 5) minimnya kesadaran anggota membayar upah; 6) kelemahan sumber daya finansial; 7) posisi tawar yang lemah; dan 8) visi dan misi yang kurang tajam dan tidak jauh ke masa depan (M. S. Hidayat, 2012: 23).

Kelemahan yang lain juga karena di perusahaan tidak ada Dewan Perusahaan.Pemerintah melalui PERPU No.45 Tahun 1960 memberikan kesempatan bagi perusahaan negara untuk membangun bersama-sama dengan para pekerjanya Dewan Perusahaan.Untuk mengoperasikan PERPU dimaksud, dikeluarkan Peraturan Pemerintah No.25 Tahun 1961 yang pada intinya mengatur bahwa di tiap-tiap perusahaan negara, agar segera dibentuk Dewan Perusahaan dengan persetujuan dari Menteri Perburuhan.Dengan dibentuknya Dewan Perusahaan, kerja sama dalam proses produksi atau sistem hubungan industrial dapat dibangun atas dasar semangat kebersamaan, memiliki nilai-nilai demokratis dan transparansi (Sutanto, 2002: 168; H.P. Rajagukguk, 2002:168). Tujuan dewan perusahaan adalah menyelenggarakan ekonomi gotong-royong atau ekonomi kolektif antara peserta produksi dan masyarakat. Sejak diundangkannya, undang-undang ini tidak pernah efektif hingga saat ini meskipun belum pernah dicabut (A. Uwiyono, 2002: 156; H.P. Rajagukguk, 2002:155).

Dewan Perusahaan dapat didirikan kembali di perusahaan dengan inisiatif dari pihak Serikat Pekerja/Serikat Buruh, tentunya dengan persetujuan perusahaan. H.P. Rajagukguk sependapat dengan golongan-golongan yang tidak menghendaki adanya pertentangan dan mengidam-idamkan kerukunan, melihat pada co-determination sebagai cara untuk mengakhiri perjuangan berdasarkan pertentangan kelas.(H.P. Rajagukguk, 2002: 156).

Co-determination di Jerman, di mana perusahaanperusahaan dengan lebih dari 500 orang pekerja, harus membentuk dewan pengawas yang terdiri dari perwakilan yang dipilih oleh para pekerja dengan dilandaskan kepada aturan dari 1/3 keikutsertaan. Namun demikian, pengelolaan perusahaan, dibatasi oleh perusahaan dan pemegang saham serta pengawas (Jeans Kirchner dan Sascha Morgenroth, 2010: 39). Co-determination menjadikan korporasi-korporasi Jerman lebih demokratis, lebih bertanggungjawab dan resposif terhadap kepentingan pekerja. Korporasi bisa saja kurang responsif terhadap kepentingan pemegang saham dalam meningkatkan pengembalian ekonomis perusahaan sekaligus kurang responsif terhadap kepentingan konsumen pada harga murah. Perusahaan bisa saja menjadi tidak kompetitif dan bangkrut. Namun, wakil-wakil pekerja bertindak sacara rasional demi kepentingan konstituenkonstituen mereka, pengaruh utamanya ialah meningkatnya fraksi pendapatan korporasi yang akan menjadi milik pekerja, dengan mengorbankan pihak pemegang saham (James S. Coleman, 2010: 769-770).

Dewan perusahaan juga harus melakukan kegiatannya berdasarkan pada peraturan ketenagakerjaan dan sistem hubungan industrial. Di sebagian besar negara, seperti Jerman, akan ada saluran multi representasi, dimana Dewan perusahaan merupakan wakil pekerja di perusahaan dan wakil pada perundingan kolektif yang terjadi melalui serikat buruh. Jadi kegiatan kerja jangka pendek, Dewan kerja tidak menggantikan serikat buruh, melainkan melengkapi dan beroperasi secara independen pada waktu tawar-menawar dalam perjanjian kerja kolektif (PKB, pen.) Jadi Dewan Kerja dapat berkontribusi pada pengembangan bentukyang lebih kooperatif dalam hubungan kerja (Glenn Patmore, 2010: 17).Co-determination ini hendaknya ditanggapi positif oleh pihak perusahaan, dengan membentuk dewan perusahaan. Sikap berseberangan dengan pihak pekerja atau sebaliknya 
dapat diakhiri dengan membangun kebersamaan berdasarkan nilai-nilai silaturrahmi, kepatutan, kerukunan dan saling mempercayai.

Pengusaha yang baik, hendaknya meniru keteladanan Robert Owen, sebagai pengusaha yang sangat memperhatikan kesejahteraan pekerjanya. Robert Owen orang pertama yang menggunakan istilah sosialisme, sebagai direktur dari sebuah pabrik tenun pada masa revolusi industri, Robert Owen tidak menggunakan seluruh usahanya hanya semata-mata mengejar keuntungan yang sebesar-besarnya bagi pabriknya sendiri, tetapi dia juga memikirkan tingkat kehidupan ekonomi para buruhnya. Kecintaaannnya kepada buruhnya, diungkapkannya bahwa Segera diperhatikan dengan berhati-hati memperlakukan mesin-mesin mati itu dan jangan diabaikannya atau disia-siakannya mesin-mesin yang hidup itu. Apakah tidak lebih baik kalau mesin-mesin hidup ini yang kontruksinya jauh lebih baik dijaga daripada perkakas-perkakas tenun dan gelendong-gelendong benang?" (Andjar Pachta W. et.al., 2007: 33):

Owen kemudian mengambil langkah-langkah kongkret sebagai tindak lanjut dari hasil pemikiran-pemikiran idealisnya, antara lain dengan: a) Memperpendek jam kerja dari 17 jam menjadi 10 jam/hari; b) Menaikkan tingkat upah; c) Memberikan jaminan sosial untuk hari tua; d) Mendirikan sekolah bagi anak-anak buruh; e) Menolak mempekerjakan anak-anak di bawah umur 10 tahun; f) Melarang orang mendirikan toko atau warung disekitar pabrik dan menganjurkan buruhnya untuk mendirikan toko atau warung sendiri yang menyediakan barang-barang yang diperlukan; dan g) Mencoba membentuk masyarakat baru di mana dengan mengembangkan kehidupan sosial-ekonomi yang sehat, masyarakat baru itu disebutnya community yang terdiri dari unsur seluruh pekerjaan bersama dan hasilnya untuk dijadikan sebagai milik bersama(Andjar Pachta W. et.al., 2007: 34).

Pemikiran idealis Owen, tidak lepas dari suara hati nuraninya melihat penderitaan sesama manusia (humanis), sebab pemikiran saja dipengaruhi oleh lingkungan sekitarnya. Tindakan pemerasan dan perlakuan tidak adil yang banyak dilakukan oleh pengusaha zaman itu, karena tuntutan untuk memperoleh keuntungan yang sebesar-besarnya dengan pengeluaran yang sekecil-kecilnya (kapitalis).

Tindakan Owen selaras dengan teori keseimbangan kekuatan (The theory of a balance of power) menyatakan bahwa hubungan (antara pengelola dan tenaga kerja) melibatkan masalah keseimbangan ekonomi antara kekuatan tenaga kerja melawan kekuatan modal. Teori keseimbangan kekuatan ini berdasarkan keragaman asumsi yang tak terelakkan dan perlunya kepentingan. Ini adalah teori dunia lama yang tradisional, bukan teori abad ke-20 Amerika Serikat. Teori abad ke-20 Amerika Serikat menyatakan bahwa hubungan itu (antara pengelola dan tenaga kerja) tergantung pada kepentingan bersama, pemahaman, dan goodwill (Charles W. Baird, 1987: 939-940).

Serikat Pekerja/Serikat Buruh sebagai pengayom tenaga kerja, harus mengupayakan agar anggotanya memiliki keterampilan atau ahli dibidangnya. Serikat Pekerja/Serikat Buruh harus bekerjasama dengan lembaga keterampilan, Diklat Kemenakertrans/Disnakertrans, BLK, dan kursus-kursus keterampilan; agar calon pekerja dan pekerja dapat meningkatkan keterampilan dan keahliannya. Organisasi Serikat Pekerja/Serikat Buruh yang didukung oleh para anggota yang profesional, membuat posisi tawar Serikat Pekerja/Serikat Buruh menjadi berwibawa dalam memperjuangkan upah yang layak dan sangat diperhatikan oleh pengusaha.

Kegiatan konstruktif dari Serikat Pekerja/Serikat Buruh dalam upaya memperjuangkan upah yang layak dan pensejahteraan pekerja, antara lain: 1) Muchtar Pakpahan (dalam http://nasional.sindonews.com/read/ 1028249/ 149 /sbsi-kukuhkan-koperasi-buruh-1438398904, 1 Agustus 2015) ketika mendirikan koperasi Serikat Buruh Sejahtera Indonesia (SBSI) di Jakarta, menyatakan tujuan koperasi dari dana yang terkumpul untuk simpan pinjam/pengembangan usaha, keperluan mendadak anggota dan mempererat hubungan para anggota; dan 2) Yudi Prasetyo (dalam http:/ /www.spjict.or.id/sp-jict-salurkan-beasiswa-untuk-330-anakburuh/, 1 Nopember 2012) selaku penaggungjawab Serikat Pekerja PT. Jakarta International Container Terminal (SP. JICT), dalam penyaluran beasiswa bagi 330 anak tenaga kerja bongkar-muat (TKBM) di Pelabuhan Tanjung Priok, Jakarta.

Kegiatan di atas, sejalan dengan fungsi Serikat Pekerja/ Serikat Buruh dalam pensejahteraan anggotanya.Oleh karena itu, secara organisasi, fungsi Serikat Pekerja/Serikat Buruh yang lemah, menjadi kuat jika Serikat Pekerja/Serikat Buruh dan anggota bersatu dan rukun dengan kepemimpinan yang 


\section{MEDIA
HUKUM}

Tabel 3

Tenaga Kerja Menurut Jenis Kegiatan Utama

\begin{tabular}{llllll}
\hline & 2011 & & 2012 & & 2013 \\
& FEB & AGS & FEB & AGS & FEB \\
\hline 1. Angkatan kerja & 119.40 & 117.37 & 120.41 & 118.05 & 121.19 \\
$\quad$ Bekerja & 111.28 & 109.67 & 112.80 & 110.81 & 114.02 \\
Penganggur & 8.12 & 7.70 & 7.61 & 7.24 & 7.17 \\
2. Tingkat partisipasi angkatan kerja (\%) & 69.96 & 68.34 & 69.66 & 67.88 & 69.21 \\
3. Tingkat pengangguran terbuka (\%) & 6.80 & 6.56 & 6.32 & 6.14 & 5.92 \\
4. Pekerja tidak penuh & 34.19 & 34.59 & 35.55 & 34.29 & 35.71 \\
$\quad$ Setengah penganggur & 15.73 & 13.52 & 14.87 & 12.77 & 13.56 \\
$\quad$ Paruh waktu & 18.46 & 21.06 & 20.68 & 21.52 & 22.15 \\
\hline
\end{tabular}

Sumber BPS, 2013, sudah diolah kembali. Terjadi penurunan TPT di Indonesia tetapi masih relatif tinggi pada kisaran $5.91 \%$. Jumlah pekerja tidak penuh masih tinggi pada kisaran 35,71 Juta.

Sumber: Aviliani, Biaya Tenaga Kerja di Indonesia, Makalah Disampaikan pada Forum Konsolidasi Dewan Pengupahan se Indonesia, Jakarta, tanggal 3-5 September 2013.

amanah. Hubungan yang harmonis antara Serikat Pekerja/ Serikat Buruh dengan anggota, Apindo/Kadin dan Pemerintah; terjalin dengan baik karena mematuhi UU. Serikat Pekerja/Serikat Buruh.

Filosofi HIP, dengan basis kaedah "kearifan lokal" Indonesia. HIP didasarkan nilai kemitraan dalam bingkai asas kekeluargaan. Mustafa menjelaskan bahwa nilai kemitraan yang produktif, mesti diupayakan dengan pendekatan strategis dengan memperhatikan faktor-faktor yang potensial menjadi ancaman dan gangguan hubungan industrial itu sendiri adalah soal pengupahan.Pokok masalah pengupahan adalah soal kelayakan, keadilan, kepastian dan kesinambungan hubungan antara pengusaha dan pekerja. Menajemen pengupahan, menjadi bagian strategis dari manajemen SDM, Fungsinya di perusahaan meliputi: a) komitmen perusahaan; b) organisasi; c) peraturan-peraturan pengupahan; d) standard operating procedure (SOP); dan e) sarana dan prasarana administrasi (Mustofa, 2013: 7).

Kemitraan pengusaha dan pekerja, pada dasarnya samasama mematuhi UUK yang tunduk pada UUD 1945. Tujuan pengusaha tentunya paralel dengan tujuan negara, salah satunya adalah memajukan kesejahteraan umum. Pembayaran upah di bawah Upah Minimal Propinsi termasuk Upah Minimal Propinsiitu sendiri, merupakan sikap yang tidak mencerminkan tujuan dalam Pembukaan UUD 1945, yaitu keadilan substantif.

Dalam negara sekuler yang dibangun di atas cinta diri, kebenaran yang sebenarnya telah tersembunyi oleh karena ulah para warganegara yang secara sadar hendak mematikan kebenaran itu. Karena kebenaran telah tersembunyi dan dipisahkan dari keadilan, maka lembaga-lembaga pengadilan yang seyogyanya menegakkan keadilan, telah dipenuhi oleh ketidakadilan. Itulah akibatnya apabila kebenaran dipisahkan dari keadilan (F. Budi Hardiman, 2009: 164).Satjipto Rahardjo, menyatakan bahwa keadilan substantif tersebut tidak cukup dengan hanya pernyataan politik pada waktu Pemilu dari pasangan calon Presiden dan Wakil Presiden, tapi setelah menjadi Presiden dan Wakil Presiden dapat mematuhi hukum yang bersifat progresif yang tertuju pada hukum substantif (Satjipto Rahardjo,2009:12; Satya Arinanto dan Ninuk Triyanti, 2009:4). Berdasarkan data BPS keadaan tenaga kerja yang masih banyak menganggur dan setengah menganggur, dapat diperhatikan pada tabel di bawah ini (Avilian, 2013).

Memperhatikan data pada tabel di atas Pemerintah harus berusaha lebih keras untuk menciptakan lapangan pekerjaan bagi penganggur yang berjumlah 7,17 juta, pekerja yang bekerja secara tidak penuh berjumlah 35, 71 juta, setengah 
penganggur 13, 56 juta dan bekerja paruh waktu 22,15 juta. Di samping itu pemerintah harus mendidik dan melatih Sumber daya Manusia yang mampu bekerja secara professional untuk memenuhi persyaratan dari pasar kerja. Pekerja professional di samping bekerja yang menguntungkan diri dan keluarganya, juga sangat menguntungkan Negara Republik Indonesia karena menjadi sumber pendapatan Negara dari sektor pajak penghasilan, pertambahan nilai dan bumi/bangunan. Apabila pengangguran dapat diminimalisir, maka problem sosial seperti kejahatan dapat berkurang secara signifikan.

\section{SIMPULAN}

Eksistensi Serikat Pekerja/Serikat Buruhdalam upaya mensejahterakan pekerja: pertama, SP/SB dalam pengelolaan organisasinya belum profesional, menurut Anggaran Dasar dan Anggaran Rumah Tangga (AD/ART) yang berdasarkan UU.No. 21 tahun 2000, sehingga posisi tawar-menawar dengan pengusaha sangat lemah dalam memperjuangkan hak-hak normatif anggotanya untuk dapat hidup sejahtera. Di samping, pengusaha tidak mudah untuk meningkatkan kualitas dan kuantitas hasil produksi dan jasa, dikarenakan tingkat keterampilan pekerja pada umumnya masih rendah. Kedua, Serikat Pekerja/Serikat Buruh belum melaksanakan amanat UU. No. 21 Tahun 2000. Tujuannya memberikan perlindungan, pembelaan hak dan kepentingan serta meningkatkan kesejahteraan yang layak bagi pekerja/buruh dan keluarganya, jauh dari kenyataan. Kekuatan seluruh anggota Serikat Pekerja/Serikat Buruh ditambah pekerja informal yang belum menjadi anggota (60 \% dari total pekerja), akan meningkatkan daya tawar-menawar dan wibawa dengan pengusaha; dan ketiga, eksistensi Serikat Pekerja/Serikat Buruh, masih menghadapi kendala umum dalam melaksanakan kewajibannya mensejahterakan pekerja, disebabkan: 1) tidak memperjuangkan kepentingan anggota, tapi cenderung sibuk dengan kegiatan/alat politik dari partai; 2) kepentingan pribadi/golongan pengurus, menjadi alasan perpecahan dari waktu ke waktu; 3) kualitas dan kuantitas kepemimpinan; 4) kurangnya kesadaran menjadi anggota Serikat Pekerja/Serikat Buruh, termasuk kewajiban membayar iuran anggota; 5) visi dan misi tidak berprespektif ke masa depan

\section{SARAN}

1. Serikat Pekerja/Serikat Buruhdan anggotanya, harus bekerja dengan profesional dalam menjalankan organisasinya menurut AD/ART yang berdasarkan UU. No. 21 tahun 2000. Serikat Pekerja/Serikat Buruh menuntut Pemerintah secara terus menerus mendidik dan melatih anggota Serikat Pekerja/Serikat Buruh, agar menjadi profesional di bidangnya untuk memenuhi persyaratan dari pasar kerja. Sebab pekerja professional, dapat hidup sejahtera, penyumbang pajak, dan mengurangi tingkat pengangguran, dan problem sosial lainnya.

2. Segera diupayakan dibentuknya Dewan Perusahaan, berupa kerja sama dalam proses produksi atau sistem hubungan industrial dapat dibangun atas dasar semangat kebersamaan, memiliki nilai-nilai demokratis dan transparansi. Tujuan dewan perusahaan adalah menyelenggarakan ekonomi gotong-royong atau ekonomi kolektif. Dewan Perusahaan dapat didirikan kembali di perusahaan dengan inisiatif dari pihak Serikat Pekerja/Serikat Buruh, tentunya dengan persetujuan perusahaan. Dewan Perusahaan sebagai cara untuk mengakhiri perjuangan berdasarkan pertentangan kelas.

\section{DAFTAR PUSTAKA}

\section{Buku}

Arinanto, Satya, dan Ninuk Triyanti, 2009, Memahami Hukum, Dari Konstruksi sampai Implementasi, Jakarta: Rajawali Pers.

Boje, Thomas P. and Bengt Furaker, 2003, Post-Industrial Labour Markets, Profiles of North America and Scandinavia, New York, Routledge.

Bronstein, Arturo, 2009, International and Comparative Labour Law, Current Challengers, New York: Palgrave MacMillan

Burkett, Brian, 2006, The International labour dimension: an introduction; Dalam: Globalization and the Future of Labour Law, Cambridge University Press.

Colemen, James S., 2010, Foundation of Social Theory, The Belknap Press of Harvard University Press, 1994; Penerjemah: Imam Muttaqien dkk, Dasar-dasar Teori Sosiologi, Bandung: Nusa Media.

F., Budi Hardiman, 2009, Demokrasi Deliberatif, 
Menimbang Negara Hukum dan"Ruang Publik dalam Teori Diskursus Jurgen Habermas, Yokyakarta, Kanasius.

George, Susan,2002 "Republik Pasar Bebas, Menjual Kekuasaan Negara, Demokrasi dan Civil Society kepada Kapitalisme Globa”, terjemahan Esti Sumarah, Jakarta, PT. Bina Rena Pariwara dan INFID

Hendratno, Edie Toet, 2009, Negara Kesatuan Desentralisasi dan Federalisme, Jakarta, Graha Ilmu, Universitas Pancasila.

Hidayat, M.S., 2012, Seabad Gerakan Buruh Indonesia, Bandung, Nuansa Aulia.

Juanda, 2008, Hukum Pemerintahan Daerah: Pasang Surut Hubungan Kewenangan antara DPRD dan Kepala Daerah, Bandung, Alumni.

Kirchner, Jeans, and Sascha Morgenroth, 2010, Executive Summery: Key Aspects of German Employment and Labour Law, dalam: Jeans Kirchner cs, Key Aspects of German Employment and Labour Law, German: Springer, Heidelberg.

Murhem, Sofia, 2006, Industrial Relations in Small Enterprises in Sweden, ((Editors): Christian Dufour, Adelheid Hege, Sofia Murhem, Les relations sociales dans les petites entreprises -Une comparaison France, Suède, Allemagne, P.I.E.- Peter Lang S.A.

Patmore, Glenn, 2010, Kebahagiaan Sebagai Tujuan Hukum Perburuhan, Pusat Ketenagakerjaan dan Hubungan Hukum Ketenagakerjaan, Melbourne: Universitas Melbourne.

Pradjoto, 1983, Kebebasan Berserikat Di Indonesia, Jakarta: Sinar Harapan.

Rahardjo, Satjipto, 2009, Hukum Progresif: Aksi, Bukan Teks; Dalam: Satya Arinanto dan Ninuk Triyanti, 2009, Memahami Hukum, Dari Konstruksi sampai Implementasi, Jakarta, Rajawali Pers.

Rajagukguk, H. P., 2002, Peran Serta Pekerja Dalam Pengelolaan Perusahaan (Co-determination), Jakarta: Yayasan Obor Indonesia.

Soto, Hernando De, 1990, The Other Path, the Invisible Revolution in the Third Work, Diterjemahkan Masri Maris, 1991, Masih Ada Jalan Lain: Revolusi Tersembunyi di Negara Dunia Ketiga, Jakarta: Yayasan Obor Indonesia.

Sutanto, 2002, Usaha-usaha Pengembangan Dewan Perusahaan dan Perbandingannya di Beberapa Negara; Dalam: H.P. Rajagukguk, Peran Serta Pekerja Dalam
Pengelolaan Perusahaan (Co-determination), Jakarta: Yayasan Obor.

Tumpa, Harifin A., 2010, Peluang dan Tantangan Eksistensi Pengadilan HAM di Indonesia, Jakarta: Prenada Media.

Uwiyono, A., 2002, Perkembangan Co-determination di Jerman; Dalam: H.P. Rajagukguk, Peran Serta Pekerja Dalam Pengelolaan Perusahaan (Co-determination), Jakarta: Yayasan Obor.

W., Andjar Pachta, dkk, 2007, Hukum Koperasi Indonesia: Pemahaman, Regulasi, Pendirian, dan Modal Usaha, Jakarta, Prenada Media Group.

Wijayanti, Asri, 2009, Hukum Ketenagakerjaan Pasca Reformasi, Jakarta, Sinar Grafika.

\section{Jurnal}

Baird, Charles W.,1987, "Labor Law and Labor Mangement Corporation: Two Incompatible Views", Cato Jurnal, Vol. 6, No.3.

\section{Makalah}

Aviliani, "Biaya Tenaga Kerja di Indonesia”, Makalah untuk Seminar Nasional "Forum Konsolidasi Dewan Pengupahan se Indonesia”, oleh Kemenakertrans, Jakarta: 3-5 September 2013.

Ibrahim, Zulkarnain, "Dinamika Gerakan SP/SB di Indonesia”, Makalah untuk Seminar di SPSI Sumsel, tahun 2011.

Mustofa, "Sistem Manajemen Pengupahan Pekerja Perusahaan, Upaya Strategis untuk Menjaga Hubungan Industrial yang Produktif", Makalah untuk Seminar "Forum Konsolidasi Dewan Pengupahan se Indonesia”, Jakarta, tanggal 4 September 2013.

Ritonga, Rizali, 2012, "Tinjauan KHL Sebagai Basis Penetapan Upah Minimum”, Makalah untuk Seminar "Strategy Pengupahan yang Layak" Hotel Ciputra Jakarta, 15 Maret 2012.

Rooij, Peter van, "Pekerjaan yang Layak dan Upah yang Layak", Makalah untuk Seminar "Forum Konsolidasi Dewan Pengupahan se Indonesia”, Jakarta, tanggal 4 September 2013.

\section{Internet}


VOL. 23 NO. 2

Muchtar Pakpahan, SBSI Kukuhkan Koperasi Buruh, http://nasional.sindonews.com/read/1028249/ 149/sbsi-kukuhkan-koperasi-buruh-1438398904, diunduh tanggal 19-6-16.

Yudi Prasetyo, SP JICT Salurkan Beasiswa Untuk 330 Anak Buruh, http://www.spjict.or.id/sp-jictsalurkan-beasiswa-untuk-330-anak-buruh/, diunduh tanggal 19-6-16. 